\title{
Öğretmen Adaylarının Stres Nedenleri
}

\author{
Doç. Dr. Burhan AKPINAR* \\ Fırat Üniversitesi, Eğitim Fakültesi, Eğitim Bilimleri Bölümü, Elazı̆̆ / Türkiye
}

\begin{abstract}
Özet
Bu araştırmada amaç, öğretim sürecinde öğretmen adaylarında strese yol açan nedenleri belirlemektir. Toplam 1214 öğretmen adayının katıldığı araştırmada, veriler açık uçlu sorularla elde edilmiştir. Verilerin analizinde frekans ve yüzde alma teknikleri kullanılmıştır. Analiz sonuçlarına göre, öğretmen adaylarında strese yol açan nedenler sırayla şu şekilde ortaya çıkmıştır: KPSS, kişisel nedenler, öğretimsel sorunlar, ailevi nedenler, manevi (ruhsal) nedenler, maddi sorunlar, öğretim üyesi tavrı, sağlık, duygusal ilişkileri ve politik sorunlar. $\mathrm{Bu}$ verilerden hareketle, öğretmen adaylarında stres yol açan başat nedenin "atanma sorunu” olduğu belirlenmiştir. Bir öğretmen yetiştirme sorunu olarak ele alınabilecek olan bu stresin, öğretmen adaylarında, gerek öğrenimleri sırasındaki akademik başarıları ve gerekse atandıklarında öğretmenlik hizmetini icra ederken etkili ve verimli öğretim yapmalarını olumsuz etkileyeceği öngörülebilir. Dolayısıyla Millî Eğitim Bakanlığı'nın bu konuda alternatif atama yöntemleri üzerinde düşünmesinde yarar vardır.
\end{abstract}

Anahtar Kelimeler: Stres; Öğretmen adaylarında stres; Öğretmen yetiştirmede stres; Öğretmen atama sorunu; Maneviyat ve stres. 


\title{
The Causes of Stress of Teacher Candidates
}

\begin{abstract}
The purpose of this study is to determine the causes of stress of teacher candidates during education process. The data was collected by open-ended questions through this study in which 1214 teacher candidates took part. In order to analyze the data, frequency and percentage techniques were used. According to the results of the analysis, KPSS, personal reasons, educational struggles, family problems, mental reasons, financial problems, attitudes of instructors, health, relations with opposite sex and political issues can be counted among the causes of stress. With the help of these data, it is determined that being appointed is the main reason of stress of teacher candidates. It can be proclaimed that this source of stress which can be defined as the teacher training problem has negative effect on teacher candidates in their academical improvement and during teaching process after the appointment as well. Hence The Ministry of Education should think about alternative appointment methods.
\end{abstract}

Keywords: Stress; Stress of teacher candidates; Stress in teacher training; The problem of appointment; Psychology and stress.

\section{Extended Summary}

\section{Purpose}

Stress is one of the important teaching and learning variance affecting classroom atmosphere. Therefore; it is quite normal that the teacher training process contains stress. Stress could be beneficial to a certain level, but it can turn into an obstacle above crucial threshold. So stress which should be on the level of "enough is as good as a feast" can be discussed as the problem of teacher training.

Stress is a leading problem which teacher candidates should cope with in Turkey. Some of the main reasons of this problem can be 
defined as the nature of higher education, the features of the developmental process in which the young are, personal and family problems and unbalanced situation between teacher training system and their employment need. As a result of this unbalanced situation "the problem of being appointed" is the most remarkable one. The source of this problem is disconsistancy between teacher training system and employment problem in Turkey.

Being exposed to stress during training process affects teacher candidates and prevents them to be well trained. Besides, if the stress is not controlled, it can turn into a chronical illness and become a personality trait. This kind of stress makes teachers candidates imposible to fulfill the necesities of the job after being appointed, because being a teacher requires patience, compession and flexibility. Due to all these effects, stress can be discussed as the "matter of teacher training”. To cope with this matter, first of all, the problem should be analyzed throughout all aspects. For this analysis, the expression and thought of teacher candidates are essential. The purpose of this study is to determine the causes of stress of teacher candidates during their education process.

\section{Methods}

Population of this study is teacher candidates studying at faculties of education at Frrat, İnönü, Bartın, Mustafa Kemal, Siirt and Ağrı İbrahim Çeçen Universities in 2012-2013 education year. Sample is 1214 teacher candidates from the population. Dispersions of the candidates according to demographic variances in this study are as follows: 
Gender $\left(\right.$ Female $_{n}=743$, Male $\left.=471\right)$, Age (17-24 Age $_{n}=1134$, over $25_{\mathrm{n}}=80$ ), Educational backround (Normal education $\mathrm{n}_{\mathrm{n}}=657$, Night shift education $_{\mathrm{n}}=557$ ) and willingness of department preferance (willing$1 y_{n}=872$, unwillingly $=342$ ). For this descriptive study, data was collected through questionnaire. In order to analyze the data, frequency and percentage techniques were used and the data was classified under certain titles.

\section{Results}

In this study, the answers of teacher candidates were classified under twelve subtitles. According to this study, the most important reason causing stress is KPSS(\% 27) and others are; personal reasons (\% 17.9), problems about lectures (\% 16.3), family reasons $(\% 6,6)$, mental (psychological) reasons (\% 6.5), financial problems (\% 6.3), attitudes of lecturers (\% 5.2), health problems (\% 4.9), relation with opposite sex (\% 4.8) and idealogical problems (\% 4.5).

\section{Discussion}

For nearly one-third of teacher candidates (\% 27), KPSS exam is sickeningly source of stress. This examination prevents them to be trained efficiently and risks their academical improvement as well as being sufficient and effective while teaching after appointment as well. This finding is supported with some other similar study findings. The problem is mainly based on unbalanced situation between teacher training system and employment problem in Turkey. Therefore, the coordination between Council of Higher Education, which trains 
teachers, and Ministry of Education, which employs them, is required for a solution.

The second reason of stress for teacher candidates is "personal reasons" which is mainly a generation matter. The age group of these candidates is mostly (\% 93.3) $17-24$ and is era is generally called adolascence and early adulthood which is a stormy period of human life according to the science of psychogy. To cope with this stress, some lessons and activities can be added to the current curriculum.

The third reason of stress for teacher candidates is problems about lectures. This finding is similar to some other findings about this subject. These problems can be listed as ambiguity of the lecture aims, indefiniteness at types, timing, announcement and evaluation of the exams, difficulties to reach the sources of documents and physical conditions of the classrooms. For a solution to this matter, instructors can be trained in the field of pedagogy and communication.

The fourth reason of stress for teacher candidates can be related with family matters, personal reasons and culture. In relation with this, providing contribution for teacher candidates to cope with the stress can be useful.

Another remarkable finding is expressions of candidates being exposed to stress because of mental (psychological) problems. One of the most reasonable reason of this is due to Turkish Educational System has a positivist character which is the result of inspiration of the West. As a result of this, practical education process skips to enlighten 
the person in aspects of moral and material needs, but it gives metarialistic information or helps people to be specialized for working life. Thus, the minds of teacher candidates are satisfied with the information they get, but they are not sufficient for the mental and spiritual part of human; kind whereas the man consists of spirit and body. For a balanced personal development, all aspects of the man should be improved with the help of education. This situation is essential for teacher candidates as the man to be trained sufficiently and to perform their job effectively. So, as a result of positivist education which is being carried on at education faculties, it is quite normal to cause mental gaps in a teacher candidates' mind and spirit.

The fifth reason of stress for teacher candidates is financial problems. In fact this one is rather familiar to us. Because it is obvious that most of the students studying at faculty of education come from low socio-economic families.

Another finding of the study is the attitude of the instructors and lecturers causes stress. This problem can be caused by the personality of instructors, teaching methods they use their style of classroom management or generation gap between students and instructors. For this matter, it may be useful to train instructors on teaching skills, communicational skills and classroom management.

The other reasons of stress for teacher candidates are health problems, emotional and ideological matters. These are mostly releated with the age in which the candidates live (except health). As a con- 
tribution, university management should organize some activities for the teacher candidates about the above mentioned subject.

\section{Conclusion}

Being a teacher is a job which requires a great deal of patience, tolarance and flexibility. In order to perform this job sufficiently it requires having above mentioned features of teacher candidates. The high level of stress which is not controlled is a kind of illness that hampers having these features of teacher candidates. Therefore, to perform their job productively and effectively, it is essential that teacher training process be purged from stress. During this process there are many reasons which cause stress for teacher candidates according to the results of this research. KPSS, personal reasons, educational struggles, family problems, mental reasons, financial problems, attitudes of instructors and lecturers, health problems, relations with opposite sex and political issues can be counted as reasons. Although these problems cannot be taken out completely, the level of them can be lessened by taking some precautions. In macro perspective to overcome the problem altogether, it is crucial to produce some approches which balance the gap between teacher training system and employment problem. In micro perspective, regulating social environment of universities and faculties according to principle of anti-stress, improving teaching and communicational skills of instructors and contributing to teacher candidates to deal with stress can be recommended. 


\section{Giriş}

Öğrenme süreci, doğası gereği stresli bir etkinlik olup, bu sürecin formal olarak yürütüldüğü okullar, toplumun en stresli ekolojisidir (Yıldırım ve Buluç, 2004). Bundan dolayı, ciddi bir öğrenme sürecini gerektiren öğretmen yetiştirmenin de, belli oranda stres içermesi doğaldır. Bu stres, belirli bir düzeyi aşmadıkça ve kontrol edilebildiği sürece, öğretmen adaylarının, öğretim sürecinde uyarıcıları daha iyi kodlaması için faydalı olabilir. Çünkü öğrenme, asgari olarak belli bir uyanıklık hâlini gerektirir. Bu noktada, organizmayı uyaran bir etken olan stres, insana enerji veren tek çâredir (Albert, 2003) (akt; Y1lmaz, 2006). Bu bağlamda stres, öğretmen adayları için, sınıf iklimini etkileyen önemli bir ögrenme (Durmuş ve Aşçığlu, 2005; Nalçacioğlu, 2010) ve ögretme değişkeni (Avşaroğlu, 2007) olarak nitelendirilebilir. Nitekim Yörükoğlu'na (1992) göre, her birisi birer öğrenci olan öğretmen adayları, sadece zekâsı ve yeteneklerini kullanarak öğrenmez, stresle yakından ilişkili olan duyguları ile de öğrenir (akt; Demir, 2002).

Ancak öğrenmeyi sağlama bakımından, belirli bir düzeyi aşmayan ve kontrol edilebildiğinde faydalı olarak nitelenen stres, belirli bir eşiği aştığında, öğrenmenin sağlanması önünde ciddi bir engele dönüşebilir (Engin, Demirci ve Yeni, 2013). Dolayısıyla öğretim sürecinde stres, "azı karar, çoğu zarar" olarak ifâde edilebilecek olan bir değişkendir. Bu çalışmada stres kavramı, öğrenmenin gerçekleşmesini olumsuz etkileme riski taşıyan yüksek düzeyde ve kontrol edilmeyen 
stres anlamında ele alınmış ve bir öğretmen yetiştirme sorunu olarak irdelenmiştir.

Stres konusu, Türkiye'de öğretmen yetiştirmede hizmet öncesi süreç bağlamında ele alındığında, öğretmen adaylarının baş etmek zorunda kaldığı sorunların başında gelmektedir. $\mathrm{Bu}$ sorunun temel nedenleri olarak, yükseköğretimin doğası, (Avşaroğlu ve Üre, 2007; Balkıs, Duru, Buluş ve Duru, 2011; Bozkurt, 2004; Deveci, Çalmaz ve Açık, 2012; Durna, 2006; Temel, Bahar ve Çuhadar, 2007), yükseköğretim gören öğretmen adaylarının içinde bulundukları gelişim döneminin özellikleri, (Baloğlu ve Bardakçı, 2010; Kara, 2009; Koç, 2006), kişisel ve ailevî sıkıntılar ile öğretmen yetiştirme ve istihdamındaki arz-talep dengesizliği sayılabilir. Bu dengesizlik sonucunda ortaya çıkan ve öğretmen adaylarının 'atama sorunu' olarak adlandırılan sorun, bunlardan en dikkat çekici olanıdır. Bu sorun, büyük oranda üniversitelerin, Millî Eğitim Bakanlığı'nın (MEB) ihtiyacından fazla öğretmen yetiştirmeyle ilişkilendirilebilir. Önceleri öğretmen yetiştiren Yüksek Öğretim Kurulu (YÖK) ile yetiştirilen bu öğretmenleri istihdam eden MEB arasındaki koordinasyon eksikliğine dayalı olan bu sorun, daha sonra kamu ve vakıf üniversitelerinin âdeta yarışırcasına eğitim fakülteleri açma veya var olan eğitim fakültelerinde kontenjan artırımına gitmesi sonucunda giderek katmerleşerek, günümüze ulaşmıştır. Üniversitelerin, MEB'in ihtiyacının çok üstünde öğretmen adayı mezun etmesiyle oluşan bu katmerleşmede, fen-edebiyat fakültesini bitirip, formasyon eğitimi alan mezunların da payı unutulmama11dır. Bugün, eğitim ve fen-edebiyat fakülteleri mezunu olup da atama 
bekleyen çok sayıda öğretmen adayının mevcudiyeti, sorunun hangi boyutlara ulaştığının bir göstergesidir. Esasta öğretmen atamasıyla ilgili olan bu sorun, hizmet öncesinde ve daha öğrenimleri sırasında öğretmen adaylarını strese mâruz bırakan bir öğretmen yetiştirme sorununa dönüşmüştür. Çünkü öğretmen adayları, özellikle son sınıfa yaklaştıkça bu atama sorunuyla yüzleşeceklerini bilmektedirler. $\mathrm{Bu}$ sorun, öğretmen adaylarının, umut ve motivasyonu kırarak, onları öğretim sürecinde olumsuz etkilemektedir. Buna bir de yükseköğretim sürecinin doğası ile ergenlik döneminin özellikleri eklendiğinde, öğretmen adaylarının öğretim sürecinde diğer üniversite öğrencilerinden daha fazla strese mâruz kaldıkları söylenebilir. O kadar ki, eğer önlem alınmaz ise, öğretmen yetiştirmede hizmet öncesi öğretim sürecinin, âdeta öğretmen adaylarını 'hasta eden' bir sürece dönüşebileceği ileri sürülebilir.

Öğretmen adaylarının, başta atanma sorunu olmak üzere anılan nedenlerden dolayı hizmet öncesi öğretim sürecinde strese mâruz kalmalarının birçok sakıncası vardır. Birincisi bu stresin, öğretmen adaylarının öğrenimleri sırasındaki akademik başarılarını olumsuz etkilemesidir. Nitekim, Brown/Ralph (1999), Humphrey ve ark. (1998)'e (akt; Durna, 2006) ve Harris, Halpin ve Halpin'e (1985) (akt; Bozkurt, 2004) göre, stresin yükseköğretimde akademik başarıyı olumsuz etkilediği bilinmektedir. Bu sakınca, öğretmen adaylarının öğrenmesine bariyer oluşturarak (Tarhan, 2012), onların daha iyi yetişmesini engelleyen bir sorun olarak ele alınabilir. İkincisi bu stres, çeşitli yollarla kontrol edilemez ise, zamanla kronikleşip, öğretmen 
adayının kişilik özelliğinin bir parçası hâline gelebilir. Bu durumda öğretmen adayı, mezun olduktan sonra öğretmen olarak atandığında, kişiliğinin bir parçası hâline gelmiş stresten dolayı, işini lâyıkıyla yapamayacaktır. Çünkü öğretmenlik, büyük oranda sabır, şefkat ve esneklik gibi özelliklere sahip olmayı gerektiren bir meslektir. Henüz öğretmen adayı iken, atanma sorunu yüzünden mâruz kaldığı ve tedavi edilmediğinde zamanla kronikleşen stresli kişiliğe sahip bir öğretmenin, sabır gerektiren ve dahası bünyesinde stres barındıran öğretim sürecini hakkıyla sürdürebilmesi kuşkuludur. Eğitim gibi, toplum ve devletin büyük umut bağladığı, uğrunda büyük mâli yatırımlar yapılarak, önemli çabalar gösterilen bir konuda, bu kuşku, öğretmenlik mesleğini gerek hizmet öncesinde ve gerekse hizmet sürecinde akamete uğratma potansiyeli taşıyan ve dikkate alınması gereken bir risk olarak değerlendirilebilir.

Birçok nedeni ve boyutu olan bu atanma kaygısına dayalı stres, tamamen olmasa da kısmen azaltılması, nitelikli öğretmen yetiştirme ve öğretmenlik mesleğinin etkili ve verimli bir şekilde yürütülmesi bakımından kritik öneme sahiptir. Fidan'ın (1985) (akt; Demir, 2002) deyimiyle, "eğitim örgütlerinde, stresin oluşmaması ya da var olan stresin azaltılması için gerekli önlemlerin zamanında alınması, eğitim ve öğretimin verimliliği açısından son derece önemlidir”. Bu ise, büyük oranda devletin mâli durumu ve MEB'in öğretmen istihdamına ilişkin politikalarına bağlıdır. Bu durum, öğretmen adaylarının öğrenimleri boyunca mâruz kaldığı, atanma kaygısına dayalı stres konusunda, sözü geçen politik kararlar dışında hiçbir şey yapılamayacağı 
anlamına gelmez. Aksine, öğretmen adaylarının gerek öğretim sürecinde iyi yetişmeleri ve gerekse atandıktan sonra mesleklerini etkili ve verimli olarak icra edebilmeleri için, 'stresle baş etme yollarını öğretmek’ başta olmak üzere, yapılabilecek birçok şey vardır. Ancak bu konuda bir şeyler yapabilmek için her şeyden önce sorunun bütün boyutlarıyla tespiti gereklidir. Bunun için ise, sözü geçen sorunu bizatihi yaşayan öğretmen adaylarının konuya ilişkin görüşlerinin belirlenmesi önem arz etmektedir. Dolayısıyla amacı, öğretmen adaylarında strese yol açan nedenleri belirlemek olan bu araştırmanın, sorunun çözümüne katkı sağlaması beklenebilir.

\section{Yöntem}

\section{Evren ve Örneklem}

Bu araştırmanın evreni, Fırat, İnönü, Bartın, Mustafa Kemal, Siirt ve Ağrı İbrahim Çeçen üniversitelerinin eğitim fakültelerinde 2012-2013 öğretim y1lı I. ve II. öğretimde öğrenim gören öğretmen adayı son sınıf öğrencileridir. Örneklem ise, bu evrenden ulaşılabilen (anketi doldurmayı kabul eden) toplam 1214 öğretmen adayından oluşturulmuştur. Araştırmaya katılan öğretmen adaylarının demografik değişkenlere göre dağılımı şöyledir: Cinsiyet $\left(\operatorname{Kad}_{n}=743, \operatorname{Er}-\right.$ $\left.\operatorname{kek}_{\mathrm{n}}=471\right)$, yaş $\left(17-24\right.$ Yaşn $_{\mathrm{n}}=1134,25$ Yaş ve üzeri $\left.{ }_{\mathrm{n}}=80\right)$, öğrenim durumu (I. Öğretim $=657$, II. Öğretim ${ }_{n}=557$ ) ve bölümü tercih şekli (İsteyerek tercih edenler $r_{n}=872$, İstemeyerek tercih edenler ${ }_{n}=342$ ).

\section{Verilerin Toplanması ve Analizi}

Betimsel nitelik arz eden bu çalışmada veriler anket formu ile toplanmıştır. Araştırmacı tarafından hazırlanan ankette kişisel bilgilere 
ek olarak, "Eğitim fakültesindeki öğretim sürecinde sizi strese mâruz bırakan nedenleri sırayla yazınız.” şeklinde açık uçlu bir madde yer almıştır. Çalışmada, açık uçlu soruya verilen cevaplardan oluşan veriler, belirli başlıklar altında toplanarak yüzde ve frekans alma teknikleri kullanılarak analiz edilmiştir.

\section{Bulgular}

Araştırmada, stresle ilgili olarak sorulan açık uçlu soruya, öğretmen adayları çok çeşitli cevaplar vermiştir. Bu cevaplar belli başlıklar altında toplanarak, sorunun çerçevesi belirlenmeye çalışılmıştır. Buna göre öğretmen adaylarında strese yol açan nedenler ilişkilendirilerek, on iki başlık altında toplanmıştır. Öğretmen adaylarında strese yol açan bu nedenlere ilişkin yüzde ve frekans dağılımları Tablo 1'de görülmektedir.

Tablo 1. Öğretmen adaylarında strese yol açan nedenlerin dağılımı

\begin{tabular}{lcc}
\hline Öğretmen adaylarında strese yol açan nedenler & $\%$ & f \\
\hline KPSS & 27.0 & 329 \\
Kişisel nedenler & 17.9 & 218 \\
Dersle ilgili (öğretimsel) sorunlar & 16.3 & 199 \\
Ailevî nedenler & 6.6 & 80 \\
Manevî (ruhsal) sorunlar & 6.5 & 79 \\
Maddî (parasal) sorunlar & 6.3 & 76 \\
Öğretim elemanı tavrı & 5.2 & 63 \\
Sağlık sorunları & 4.9 & 59 \\
Gönül (duygusal) sorunları & 4.8 & 58 \\
Siyasî (ideolojik) sorunlar & 4.5 & 55
\end{tabular}


Tablo 1 incelendiğinde, öğrenimleri sırasında öğretmen adaylarında en fazla strese yol açan nedenin KPSS olduğu görülmektedir. Araştırmaya katılan öğretmen adaylarının neredeyse üçte biri (\% 27), KPSS yüzünden strese mâruz kaldığını belirtmiştir. Öğretmen atamalarında adâleti ve eşitliği temin etmek üzere, 2004 yılından beri uygulanan bu merkezî sınav sistemi, geleceğin öğretmenleri olan öğretmen adaylarını âdeta hasta eden bir sisteme dönüşmüş gibi görünmektedir. Bu hastalık, bir taraftan öğretmen adaylarının akademik başarısını olumsuz etkileyerek onların iyi yetişmelerini engellemekte, diğer taraftan da atandıklarında mesleklerini etkili ve verimli bir şekilde icra etmelerini olumsuz etkilemektedir. Nitekim stresin, öğrenmeyi engellediği bilinmektedir (Engin, Demirci ve Yeni, 2013; Onur, 1987). Bundan başka stresin, öğretmenlik mesleğinin icrasını olumsuz etkilediği de bilinmektedir (Adams, 1999; Naylor, 2001). Dolayısıyla stresli ve gergin yapıya sahip bir öğretmenin, sabır, hoşgörü ve esneklik gerektiren öğretim sürecini hakkıyla yürütebilmesi kuşkuludur.

Araştırmanın bu bulgusu, benzer çalışma bulgularıyla da desteklenmektedir. Öğretmen yetiştirme ve istihdamındaki arz-talep dengesinin sağlanamadığı bir ortamda, KPSS gibi sınavla seçme sisteminden vazgeçilmesi belki mümkün olmayabilir. Bu durumda alternatif çözüm yolları düşünülmelidir. Bunlardan birisi, yılda bir kez KPSS uygulamak yerine, bu sınavın yılda birkaç kez uygulanıp, alınan en yüksek puana göre atama yapılması olabilir. Bu uygulama, öğretmen adaylarının stres düzeyini düşürmede yarar sağlayabilir. Ayrıca 2013 yılından itibaren uygulanacak olan, adaylara genel kültür ve pedagojik 
formasyon sorularına ek olarak, alandan da soru sorulması sistemi de bu konuda yarar sağlayabilir. Ancak bunlar, sorunun çözümünde geçici tedbirlerdir. Bu sorunun kökten çözümü için, öğretmen yetiştirme ve istihdamında, Türkiye'nin kısa, orta ve uzun vadedeki demografik verileri 1şı̆̆ında, arz-talep dengesi gözetilerek, yine kısa, orta ve uzun vadeli planlamalar yapılarak, uygulanmasıdır. Bunun için YÖK ve MEB'in koordinasyonu ile Mâliye Bakanlığı gibi diğer ilgili kurumların eşgüdümüne ihtiyaç vardır. Bundan başka, YÖK tarafından son yıllarda eğitim fakültelerinin kontenjanlarının azaltılması ile bu fakültelerde ikinci öğretime öğrenci alımının durdurulması (bazı alanlar istisna olmak kaydıyla) kararı da, doğru yönde atılmış adımlardır.

Araştırmaya katılan öğretmen adaylarında strese yol açan ikinci nedenin 'kişisel nedenler' olduğu, Tablo 1'den anlaşılmaktadır. Her biri birer ergen olan öğretmen adaylarının daha çok kişisel özelliklerine bağlı olan bu sorun, büyük oranda kuşak (jenerasyon) sorunu olarak da nitelendirilebilir (Eryılmaz, 2009). Çünkü büyük çoğunluğu (\% 93.3) 17-24 yaş aralığında olan bu öğretmen adayları, ergen ve genç yetişkinler olarak nitelendirilebilir ki, bu çağ, psikolojide "firt1nalı dönem/çă̆” olarak adlandırılmaktadır (Ankay, 1992) (akt; Demir, 2002). Nitekim Tutar’a (2000) göre, bireyin kişisel özellikleri, bizzat potansiyel stres kaynağıdır (akt. Yılmaz, 2006). Kişisel stres kaynakları, biyolojik-bedensel, maddî-parasal, kişisel-duygusal, hayat tarzı ve yaş açısından ele alınabilir (Yılmaz, 2006). Ancak nedeni ne olursa olsun, kontrol edilemeyen stres düzeyinin, akademik başarı, sağlıklı kişilik ve atandıklarında mesleğini verimli bir şekilde icra etme bakı- 
mından zararlı olması, öğretmen adaylarının yaşadıkları dönem itibarıyla mâruz kaldıkları bu stres düzeyinin azaltılmasını gerekli kılmaktadır. Bunun için üniversite ve fakülte yönetimlerine önemli görevler düşmektedir. Bu konuda, programlara stresle baş etme dersleri eklenebilir, üniversite veya fakülte bazında stresle baş etme etkinlikleri düzenlenebilir ve üniversite bünyesinde uzman psikologların görev yapacağı birimler oluşturulabilir.

Tablo 1 incelendiğinde, öğretmen adaylarında strese yol açan üçüncü nedenin, derslerle ilgili sorunlar olduğu görülmektedir. $\mathrm{Bu}$ bulgu, Ardıç'ın (2009) geniş kapsamlı olarak yürüttüğü ve “öğrencilerde derslerde başarısız olma korkusunun strese yol açtığı” şeklindeki araştırma bulgusuyla paralellik göstermektedir. Öğretimsel kaygılara dayalı bu sorun, öğretmen adayları için beklenen bir durumdur. Çünkü öğretim sürecinin temel amacı olan 'öğrenme’ bünyesinde her zaman bir miktar stres barındırır. Buna üniversite eğitiminin bizâtihi kendisinin de stres kaynağı olduğu gerçeği (Özgan ve Balkar, 2008; Young, 2000; Balaban, 2000) (akt; Ayrancı ve Öge, 2011) eklendiğinde, öğretmen adaylarının öğretimsel sorunlar yüzünden strese mâruz kalması şaşırtıcı değildir. Öğretmen adaylarında strese yol açan derslerle ilgili nedenler şunlara bağlı olabilir: Dersin amacı ve sınırlarının net olmaması ile bunların önceden ilân edilmemesi, sınavların şekli, zamanı, ilânı ve değerlendirme biçimi ile ilgili belirsizlikler, dersle ilgili kaynaklara ulaşmadaki sıkıntılar ve sınıfın fizikî sorunları. Öğretmen adaylarının, derslerle ilgili olarak mâruz kaldığı stresin azaltılması konusunda, öğretim elemanları ile üniversite ve fakülte yönetimlerine önemli sorumluluklar düşmektedir. Bu konuda öğretim elemanlarının, 
çağdaş pedagojik ilkeler 1şığında öğrenci merkezli bir eğitim yaklaş1mını benimseyerek, ders ve sınavlar konusunda net ve şeffaf bir yaklaşım sergilemeleri büyük yarar sağlar. Çünkü bu durumda öğrenci, kendisinden ne beklendiğini bilecek ve ona göre kendi yol haritasını belirleyecektir. Kendisinden ne beklendiğini net olarak bilmeyen bir öğrencinin, belirsizlikten dolayı strese mâruz kalacağı açıktır. Bu konuda son y1llarda üniversitelerde Bologna Süreci doğrultusunda, öğretim elemanlarının ders izlencelerini oluşturup, dönem başında bunları web ortamında ilân etmesi gibi uygulamalar, doğru yönde atılmış adımlar olarak kabul edilebilir.

Öğretmen adaylarında strese yol açan dördüncü nedenin, ailevî nedenler (\% 6.6) olduğu, Tablo 1'den anlaşılmaktadır. Bu stres kaynağı, ailede yaşanan sorunlara ek olarak, kişisel nedenler ve kültürle de ilişkilendirilebilir. Nitekim her birisi ergen veya genç yetişkin olsa da, öğretmen adaylarının, gerek ekonomik ve gerekse karar alma bakımından, büyük oranda aileye bağımlılıkları devam etmektedir. $\mathrm{Bu}$ bağımlılık, aile bireylerinin yaşam boyu birbirini görüp, gözettiği Türk kültürünün bir eseridir. Türk kültüründe ailenin birbirini gözetmesinin olumlu yönleri olduğu gibi olumsuz yansımaları da olabilmektedir. Dolayısıyla, öğretmen adaylarının ailevî nedenlerden dolayı strese mâruz kalması, anlaşılır bir durumdur. Bununla ilişkili olarak, üniversitelerin çeşitli yollarla öğretmen adaylarına, stresle baş etme yolları konusunda destek vermesi yarar sağlayabilir.

Araştırmada dikkat çekici bir bulgu da, öğretmen adaylarının, "manevî, ruhsal sorunlar" nedeniyle strese mâruz kaldıklarını beyan 
etmiş olmalarıdır. Çünkü benzer araştırmalara bakıldığında, çağımızın hastalığı olarak nitelenen stresin kaynağı, hep maddî sahada aranmış veya gösterilmiştir. Bunun muhtemel bir nedeni, Türkiye'de eğitimin büyük oranda salt madde odaklı pozitivist bir karaktere sahip olması ve araştırmaların da bu bakış açısının hegemonyasında yürütülmesidir. Farkında olunsun veya olunmasın, Türk Eğitim Sistemi (TES) yaklaşık iki asırdır esasta, Batı'dan ilham alan pozitivist bir karaktere sahiptir (Oğuz, 2001). Bu karaktere bağlı olarak da eğitim-öğretim süreci pratikte, bireyi her bakımdan aydınlatma ve manevî tatmin sağlamayı büyük oranda görmezden gelerek, temelde madde odaklı bilgi verme veya bir mesleğe yönelik olarak beceri kazandıracak şekilde uygulanmaktadır. O kadar ki, eğitim-öğretim sürecinde, öğrencilerin (bu çalışma itibarıyla öğretmen adaylarının) birer ruh taşıdıkları âdeta görmezden gelinmiştir. Bunun eseri olarak da, öğretmen adaylarının zihnî maddî bilgilerle beslendiği hâlde, gıdası maneviyat olan ruhu âdeta aç bırakılmıştır. Ortaylı (akt; Tozlu, 2005), bu durumu, "son yüz elli yıldır sadece teknisyen yetiştiren, ama aydın yetiştiremeyen" biçiminde betimlerken, TDV (1996, s.119) ise, "Bizim eğitimimiz, geçen asrın sonrasından beri pozitivist anlayışın tesiriyle metafizik fobisine girmiştir.” şeklinde ifâde etmektedir. Topçu (1968) (akt; Deren ve Bora, 2003), daha dikkat çekici bir ifâdeyle, bu durumu "19. yüzyıl pozitivizmi ve pragmatizmden referans alan maddeci zihniyet, Türkiye'de İslâm düşmanlığına dönüşmüş" cümleleriyle dile getirmiştir. Bu konuda Schumacher (1992) (akt; Özden, 1999, s. 78), "Pozitivizm bilginin bütünlüğünü dışlamıştır.” görüşüyle, pozitivizmin, vehbî ve kesbî bilginin bütünlüğüne vurduğu darbeye işaret etmiş olsa ge- 
rektir. Batı uygarlığını "madde uygarlığı" olarak nitelendiren Guenon (1991, s.75) da, sorunu, “Ak1l, art1k sadece maddenin endüstriyel amaçlar için biçimlendirilmesinde kullanılmaktadır.” şeklinde tasvir etmiştir. Oysa en genel bir bakış açısıyla insan, madde ve manadan müteşekkildir. Lahbabi (1972, s.28), bunu, "Cisim ve ruhun birleşmesine insan denir.” şeklinde ifâde eder. Covey’e (2005) göre de insan, beden, zihin, kalp (duygular) ve ruhun toplamıdır. Dengeli bir kişilik gelişimi ve yaşam için, eğitimle insanın tüm boyutlarının geliştirilmesi ve desteklenmesi gerekir. Bu bağlamda eğitim, kişinin ruh, zekâ ve duygularının terbiye edilmesiyle birlikte bütün bir şahsiyetinin dengeli olarak büyüyüp gelişmesini hedef almalıdır (Eşref, 1991, s.13). Yakın tarihteki tecrübeler göstermiştir ki, salt madde odaklı eğitimle yetiştirilen nesiller, yoğun stresin girdabından kaçamamaktadırlar. Çünkü salt maddî aklın egemenliğine dayalı bu 'modern eğitim', toplumsal bağlar, görenek, inançlar ve duyguların yıkımını dayatmaktadır (Touraine, 2002, s.25). Bu konuda, Topçu'nun (1998, s.11) “Milletimizin üç asırdan beri geçirmekte olduğu buhranların sebebi ve kaynağı, kültür ve maarif sahalarında aranmalıdır” serzenişi dikkat çekicidir.

Madde ve mana boyutları itibarıyla bir bütün olarak gelişme, özde birer insan olan öğretmen adayının mesleğini sağlıklı olarak icra edebilmesi bakımından da çok önemlidir. Dolayısıyla eğitim fakültelerinde, neredeyse bütünüyle Batı referanslı ve pozitivist karakterli öğretim içeriği ile sürdürülen bir eğitim-öğretim sürecinin, öğretmen adaylarında manevî boşluklar oluşturması veya en azından manevî tatmin oluşturamamasına şaşmamak gerekir. Bu noktada öğretmen 
adaylarının en büyük şansızlığı, derslerinde bütünüyle Batı referanslı pozitivist bilgilerin (aslında malumatların) dağıtıcılığını üstlenen öğretim elemanları iken; en büyük şansları ise, bu bilgileri Doğu ve İslam kaynaklarıyla sentezleyerek, kültür ve tarih süzgeçlerinden geçirip öğrencileri ile paylaşan öğretim elemanlarıdır.

Araştırmaya katılan öğretmen adaylarında strese yol açan altıncı neden, maddi (parasal) sorunlardır. Bu aslında bilinen ve tanıdık bir sorundur. Nitekim günümüzde ekonomik durum, birçok kişi için önemli bir stres kaynağı olmuştur (Eren, 2004) (akt; Y1lmaz, 2006). Kaldı ki eğitim fakültelerine devam eden öğrencilerin, büyük oranda, ekonomik bakımdan çok da iyi olmayan ailelere mensup oldukları bir vakıadır (Erden, 1998). Dolayısıyla devlet ve çeşitli kurum-kuruluşların desteği olsa da, bütçeleri kısıtlı bu sosyal katmana mensup öğretmen adaylarının, maddî sıkıntılar yaşaması ve bunun da onlarda strese yol açması, anlaşılır bir durumdur. Bu konuda çeşitli kurumlar ve üniversitelerce öğrencilere sağlanan burs, kredi, barınma ve yemek desteği gibi maddî desteklerin kapsamının, ulaşım, iletişim, giyinme vb. ihtiyaçları da kapsayacak şekilde genişletilmesi yarar sağlayabilir. Buna ilâve olarak, üniversitelerde öğrencilere gelir getirici çeşitli iş imkânları sağlanarak, öğrencilerin maddi kaynaklı stres düzeyleri azaltılabilir.

Araştırmada ortaya çıkan dikkat çekici diğer bir bulgu da, öğretim elemanlarının tavrının öğretmen adaylarında strese yol açmasıdır. Bu oran büyük olmasa da (\% 5.2), öğretmen yetiştiren eğitim fakültelerinde dikkate alınması gereken bir sorun olarak kabul edilebilir. $\mathrm{Bu}$ 
sorun, öğretim elemanının seçtiği öğretim yöntemleri ve sınıf yönetim biçimiyle ilgili olabileceği gibi, bizatihi öğretim elemanının kişilik yapısından da kaynaklanabilir. Bundan başka, öğretmen adaylarının öğretim elemanı tavrından dolayı mâruz kaldığı stres, kuşak (öğretim elemanı ve öğrenciler) uyumsuzluğuna da bağlı olabilir. Öğretmen adaylarının mâruz kaldığı, öğretim elemanı kaynaklı stres düzeyini azaltmada "öğrenci memnuniyet anketleri” uygulaması yarar sağlayabilir. $\mathrm{Bu}$ anketler yoluyla öğrencilerini memnun edemeyen öğretim elemanları hakkında tedbir alınmalıdır. $\mathrm{Bu}$ tedbirler cezalandırıcı olmaktan ziyâde, eğitici ve yönlendirici olmalıdır. Bu konuda öğretim elemanlarının, öğretim becerileri, iletişim ve sınıf yönetimi vb. konularda zaman zaman eğitilmeleri de yarar sağlayabilir.

Tablo 1 incelendiğinde, sağlık sorunları (\% 4.9), duygusal sorunlar (\% 4.8) ve ideolojik sorunların da (\% 4.5), öğretmen adaylarında strese yol açtığı belirlenmiştir. Bunlardan sağlık sorunlarına bağlı stres, üniversitenin sağlık konusundaki alt yapısına ve desteğine bağlı olarak azaltılabilir. Diğer iki sorun ise, büyük çoğunluğu 17-24 yaş aralığında olan öğretmen adaylarının yaşamakta oldukları dönemle ilişkilendirilebilir. Nitekim ergenlik ve genç yetişkinlik dönemi, karş1 cinsle ilişkiler ve kimlik oluşturma bakımından bireylerin duyarlı oldukları bir dönem olarak kabul edilir. Sorun, bu dönemin sağlıklı geçirilmesini temin edecek dengeli ilişkiler kuramamakla ilişkilidir. $\mathrm{Bu}$ noktada üniversite yönetimi inisiyatif alarak, gençleri yazılı ve görsel medyanın tek taraflı yönlendirmesine bırakmamalıdır. Bunun için üniversitelerdeki sosyal etkinlikler iyi birer firsat olabilir. 


\section{Sonuç ve Öneriler}

Öğretmenlik büyük oranda sabır, hoşgörü ve esneklik gerektiren bir meslektir. Bu mesleğin hakkıyla icrası, asgari olarak öğretmenlerin bu özelliklere sahip olmasını gerektirir. Kontrol edilemeyen, yüksek düzeyde stres, öğretmenlerin sözü geçen bu özelliklere sahip olmasını engelleyen bir sorundur. Dolayısıyla mesleğini etkili ve verimli bir şekilde icra edecek öğretmenler yetiştirmek için, öğretmen yetiştirme sürecinin stresten arındırılması önemlidir. Bu süreçte, öğretmen adaylarını strese mâruz bırakan birçok neden vardır. Bu nedenler, üniversite eğitiminin zorlukları, ergenlik dönemi sorunları ve öğretmen olarak atanma sorunu olarak özetlenebilir. Öğretmen adaylarını strese mâruz bırakan bu sorunlar, öğrenimleri sırasında öğretmen adaylarının iyi yetişmesini olumsuz etkilediği gibi, ileride atandıklarında mesleklerini sağlıklı olarak icra edebilmelerini de riske sokmaktadır. Çünkü stresin bireysel ve iş yaşamında verimliliği en fazla olumsuz etkileyen unsurların başında geldiği bilinmektedir (Özer, 2012). Bu bakımdan stres, bir anlamda öğretmen yetiştirme sorunu olarak nitelendirilebilir.

Amacı öğretmen adaylarında strese yol açan nedenleri belirlemek olan bu araştırmada ulaşılan sonuçlar şöyle özetlenebilir: Araştırmaya katılan öğretmen adaylarının beyanına göre, üniversitedeki öğrenim sürecinde öğretmen adaylarında strese yol açan başlıca nedenler sırayla, KPSS, kişisel nedenler, dersle ilgili sorunlar, ailevî sorunlar, manevî sorunlar, maddî sorunlar, öğretim elemanlarının tavrı, sağlık, duygusal ve politik sorunlardır. Bunlardan öğretmen atamalarında esas alınan KPSS, esasta öğretmen yetiştirmedeki arz-talep den- 
gesizliğinden kaynaklanan bir sorundur. Öğretmen adaylarında strese neden olan kişisel sorunlar, büyük çapta yaşamakta oldukları dönemle (ergenlik) ilişkilendirilebilir. Dersle ilgili sorunların neden olduğu stres ise, öğretim sürecinin doğasından kaynaklanan bir sorun olup, dersle ilgili muğlaklık ve ilgili kaynaklara ulaşmadaki sıkıntılara bağlı olabilir. Öğretmen adaylarını strese mâruz bıraktıran ailevî nedenler ile kültürel yapı arasında bağ kurulabilir. Araştırmada ulaşılan diğer bir sonuç da, maneviyatın öğretmen adaylarında strese yol açan faktörlerden birisi olduğudur. Tek neden olmamakla birlikte, bu sorun ile eğitim fakültelerinin pozitivist karakterli program içerikleri arasında bağ kurulabilir. Öğretmen adaylarının maddi (parasal) sıkıntılardan dolayı strese mâruz kalması ise, bu öğrencilerin ekseriyetle orta ve düşük sosyoekonomik düzeye sahip ailelere mensup olmalarıyla açıklanabilir.

Dikkat çekici diğer bir araştırma sonucu da, öğretim elemanlar1nın tavrının, öğretmen adaylarında strese yol açtığıdır. Bu sorun, öğretim elemanlarının ders işlerken seçtiği yöntem, teknik ile sınıf yönetimi yaklaşımıyla ilgili olabileceği gibi, öğretim elemanının iletişim bilgi ve becerilerindeki eksiklikler ile kişilik yapılarına da bağlı olabilir. Araştırmada bunlardan başka, sağlık, duygusal ve ideolojik sorunların da öğretmen adaylarında strese yol açtığı belirlenmiştir. Sağlık hariç tutulduğunda, duygusal ve ideolojik sorunlar da, büyük oranda öğretmen adaylarının yaşamakta oldukları dönem özellikleriyle ilişkilendirilebilir. 
Sonuç olarak, bir öğretmen yetiştirme sorunu olarak ele alınabilecek olan stres, tamamen ortadan kaldırılamasa da, alınacak bazı önlemlerle azaltılabilir. Makro düzeyde sorunun aşılmasında, öğretmen yetiştirme ve istihdamına yönelik arz-talep dengesini sağlayacak politikalar üretmek önemlidir. Mikro düzeyde ise, üniversite ve fakülte düzeyinde yapılacaklar vardır. Bunlar arasında, öğrenme ve sosyal çevrenin anti-stres ilkelere göre düzenlenmesi, öğretim elemanlarının iletişim ve öğretimsel becerilerinin geliştirilmesi ve öğrencilerin öğretimsel kaynaklara daha kolay ulaşımının sağlanması gibi önemler s1ralanabilir. Ancak öğretim sürecinin doğası, ergenlik problemleri ve atanma sorunlarının öngörülebilir bir gelecekte çözüme ulaşmasının güç olduğu göz önüne alındığında, öncelikle yapılması gerekenin, öğretmen adaylarına stresle baş etme yolları konusunda profesyonel destek sağlamak olduğu söylenebilir.

\section{Kaynakça}

Adams, E. (1999). Vocational teacher stress and internal characteristics. Journal of Vocational and Technical Education, 16(1). 27 Haziran 2013, http://scholar.lib.vt.edu/ejournals/JVTE/v16n1/adams.html.

Ardıç, A. (2009). Öğrencilerde strese neden olan etkenler ve başa çıkma davranışları. Ankara: Milli Eğitim Bakanlığı, EARGED.

Avşaroğlu, S. (2007). Üniversite öğrencilerinin karar vermede özsaygl, karar verme ve stresle başa çıkma stillerinin benlik saygısı ve bazı değişkenler açısından incelenmesi. Yayınlanmamış doktora tezi, Selçuk Üniversitesi Sosyal Bilimler Enstitüsü.

Avşaroğlu, S. ve Üre, Ö. (2007). Üniversite öğrencilerinin karar ver- 
mede özsaygı, karar verme ve stresle başa çıkma stillerinin benlik saygısı ve bazı değişkenler açısından incelenmesi. Selçuk Üniversitesi Sosyal Bilimler Enstitüsü Dergisi, 18, 85-100.

Ayrancı, E. ve Öge, E. (2011). Bir vakıf üniversitesindeki öğrencilerin sınav kaygısı hakkında araştırma. Dumlupınar Üniversitesi Sosyal Bilimler Dergisi, 30, 87-102.

Balkıs, M., Duru, E., Buluş, M. ve Duru, S. (2011). Tükenmişliğin öğretmen adayları arasındaki yaygınlığı, demografik değişkenler ve akademik başarı ile ilişkisi. Pamukkale Üniversitesi Ĕ̆itim Fakültesi Dergisi, 29(1), 151-165.

Baloğlu, M. ve Bardakçı, S. (2010). Güncellenmiş öğrenci yaşamı stres envanteri'nin Türkçeye uyarlanması, dil geçerliği ve ön psikometrik incelenmesi. Türk Psikolojik Danışma ve Rehberlik Dergisi, 4(33), 57-70.

Bozkurt, N. (2004). İlköğretim öğretmenlerinde, stres yaratan yaşam olayları ve stresle başa çıkma tarzlarının çeşitli değişkenlerle ilişkisi, XIII. Ulusal Eğitim Bilimleri Kurultay1, Malatya, (6-9 Temmuz).

Covey, S. R. (2005). 8'inci alışkanlık- bütünlüğe doğru (S. Soner ve Ç. Erendağ, Çev.). İstanbul: Sistem Yayıncılık.

Demir, A. H. (2002). İlköğretim öğrencilerinde stres yaratan yönetici davranışları ve öğrencilerin başa çıkma davranışları. Yayınlanmamış yüksek lisans tezi, Ankara Üniversitesi Eğitim Bilimleri Enstitüsü.

Deren, S. ve Bora, T. (2003). Millî eğitim üzerine muhafazakâr görüşler, 22 Haziran 2013, http://www.iletisim.com.tr/kitap/mtsd/public/cilt5.htm.

Deveci, S. E., Çalmaz, A. ve Açık, Y. (2012). Doğu Anadolu'da yeni 
açılan bir üniversitenin öğrencilerinde kaygı düzeylerinin sağlık, sosyal ve demografik faktörler ile ilişkisi. Dicle Tip dergisi, 39(2), 189-196.

Durmuş, L. ve Aşçığlu, M. (2005). The effect of social isolation stress on learning in male juvenile rats. Journal of Health Sciences, 14(1), 52-56.

Durna, U. (2006). Üniversite öğrencilerinin stres düzeylerinin bazı değişkenler açısından incelenmesi. Iktisadi ve Ídari Bilimler Dergisi, 20(1), 319-343.

Engin, A.O., Demirci, N. ve Yeni, E. (2013). Stres ve öğrenme arasındaki ilişki. Eğitim ve Öğretim Araştırmaları Dergisi, 2(2), 290-299.

Erden, M. (1998). Öğretmenlik mesleğine giriş. İstanbul: Alkım Yayınları.

Eryılmaz, A. (2009). Ergenlik döneminde stres ve başa çıkma. Yüzüncü Yll Üniversitesi Ĕ̈itim Fakültesi Dergisi, 6(2), 20-37.

Eşref, S. A. (1991). İslam eğitiminde yeni ufuklar. İstanbul: Fikir Yayınları.

Guenon, R. (1991). Modern dünyanın bunalımı (N. Avcı, Çev.). İstanbul: Ağaç Yayıncılık.

Kara, D. (2009).The factors causing stress in education life and the study of students' attitudes in coping with stress according to their families' features. Selçuk Üniversitesi Sosyal Bilimler Enstitüsü Dergisi, 22, 255-263.

Koç, H. E. (2006). Üniversite öğrencilerinin utangaçlık düzeylerine göre stresle başa çıkma stratejilerinin incelenmesi. Yayınlanmamış yüksek lisans tezi, Samsun Ondokuz Mayıs Üniversitesi 
Sosyal Bilimler Enstitüsü.

Lahbabi, M. A. (1972). İslâm şahsiyetçiliği (İ. H. Akın, Çev.). İstanbul: Yağmur Yayınları.

Nalçacıŏlu, İ. (2010). Öğrenmede beyinsel incelikler. İlkadım Dergisi, 268. 29 Haziran 2013, http://www.ilkadimdergisi.net/taxonomy/term/56.

Naylor, C. (2001). Teacher workload and stress: An international perspective on human costs and systemic failure. BCTF Research Reports 3. 17 Mayis 2013, http://www.bctf.ca/ResearchReports

Oğuz, O. (2001). Yüksek Öğretim Üzerine Bazı Tespitler ve Yeniden Yapılanma Önerileri. O. Oğuz, A. Oktay ve H. Ayhan (Ed.), 21. yüzyllda ĕgitim ve Türk ĕ̆itim sistemi içinde (111-150). İstanbul: Sedar Yayınc1lik.

Onur, B. (1987). Ergenlik psikolojisi. Ankara: Hacettepe Taş Yayınc1$11 \mathrm{k}$.

Özden, Y. (1999). Ĕ̌itimde dönüşüm, ĕgitimde yeni değerler. Ankara: Pegem A Yayıncılık.

Özer, M. A. (2012). Çalışanlar için verimlilik anahtarı: Stres yönetimi. TÜHIS İş Hukuku ve İktisat Dergisi, 24(1-2), 45-66.

Tarhan, N. (2012). Stres zekânın ve öğrenmenin düşmanı. 27 Ocak 2013,http://www.haberler.com/stres-zekanin-ve-ogrenmenin-dus mani-3938306-haberi/

TDV (1996). Türk eğitim sistemi alternatif perspektif. Ankara: Türk Diyanet Vakfı Yayınları.

Temel, E., Bahar, A. ve Çuhadar, D. (2007). Öğrenci hemşirelerin 
stresle başetme tarzları ve depresyon düzeylerinin belirlenmesi. Firat Sağllk Hizmetleri Dergisi, 2(5),107-118.

Topçu, N. (1998). Bütün eserleri. Türkiye'nin maarif davası. İstanbul: Dergâh Yayınları.

Touraine, A. (2002). Modernliğin eleştirisi (H. Tufan, Çev.). İstanbul: Yap1 Kredi Yayınları.

Tozlu, N. (2005). Necmettin Tozlu ile eğitim meselelerimiz üzerine (Mülakat). Muhafazakâr Düşünce, 2(6), 141-149.

Yıldırım, F. ve Buluç, B. (2004). Sınıf ögrretmenlerinin stres kaynaklart ve başetme yolları (Kilis ili örneği), XIII. Ulusal Eğitim Bilimleri Kurultayı, Malatya, (6-9 Temmuz).

Y1lmaz, O. (2006). Stresin performans üzerine etkisi, 40'inct piyade eğitim alay komutanlı̆̆ lider personeli üzerinde bir araştırma. Yayınlanmamış yüksek lisans tezi, Isparta Süleyman Demirel Üniversitesi Sosyal Bilimler Enstitüsü. 